\title{
REVIEW
}

\section{Nitinol versus non-Nitinol prostheses in otosclerosis surgery: a meta-analysis}

\author{
Protesi Nitinol vs non-Nitinol nella chirurgia dell'otosclerosi: meta-analisi \\ L. Roque Reis, M. Donato, G. Almeida, L. Castelhano, P. Escada \\ Department of Otolaryngology of Egas Moniz Hospital, West Lisbon Hospital Centre (CHLO), NOVA Medical School, \\ Faculdade de Ciências Médicas, Lisbon, Portugall
}

\section{SUMMARY}

The aim of this study is to perform a systematic review and meta-analysis of observational studies in which hearing outcomes after primary stapes surgery have been reported. After the surgical procedure, the effectiveness of stapes surgery using nickel titanium (Nitinol) or other prostheses were systematically compared and evaluated using a meta-analytic method. A systematic search for articles before January 2017 in Embase, Medline and Cochrane Library databases was conducted. Only articles in English were included. Inclusion criteria for qualitative synthesis consisted of a population of otosclerosis patients, intervention with primary stapes surgery using the Nitinol heat-crimping prosthesis compared with other type of stapes stapedotomy prostheses, and hearing outcome. Inclusion criteria for quantitative analysis consisted of application of audiometry guidelines of the American Academy of Otolaryngology Head and Neck Surgery Committee on Hearing and Equilibrium for evaluation of conductive hearing loss. A postoperative air-bone gap (ABG) $\leq 10 \mathrm{~dB}$ was considered effective. A bias assessment tool was developed according to Cochrane guidelines. To evaluate the mean age of the samples we used the chi-square test. Of the 4926 papers identified through the electronic database search (3695 in Pubmed/Cochrane and 1231 in Embase), 540 studies matched the selection criteria (436 in Pubmed/Cochrane and 104 in Embase) after application of filters and elimination of duplicate articles. After analysis of the title and abstract, 459 were excluded (396 in Pubmed/Cochrane and 63 in Embase). Of the remaining 81 papers, 74 were excluded according to the study selection criteria. A total of seven eligible studies with 1385 subjects, consisting of 637 in the Nitinol group and 748 in the non-Nitinol group, were included in our study. There were statistically significant differences in the effectiveness of stapes surgery between the Nitinol and nonNitinol prostheses; the data showed a combined odds ratio (OR) of 2.56 (95\% CI 1.38-4.76, $\mathrm{p}=0.003)$. There were no statistically significant differences in the mean pre-operative age between Nitinol and non-Nitinol prostheses $(p=0.931)$. Our results suggest that the effectiveness of Nitinol was higher than non-Nitinol prostheses, with superiority of the number of patients with $\mathrm{ABG} \leq 10 \mathrm{~dB}$.

KEY WORDS: Stapedotomy $\bullet$ Stapedectomy $\bullet$ Stapes surgery $\bullet$ Otosclerosis $\bullet$ Prostheses

\section{RIASSUNTO}

Scopo di questo studio è stato quello di fare una revisione sistematica ed una meta-analisi di studi osservazionali in cui venivano riportati risultati audiologici dopo chirurgia stapediale. Dopo la procedura chirurgica, sono stati sistematicamente analizzati con metodo meta analitico $i$ risultati di efficacia della chirurgia stapediale usando protesi Nitinol o altre protesi. $\grave{E}$ stata fatta una ricerca sistematica dei lavori sui database Embase, Medline e Cochrane Library prima del Gennaio 2017. Sono stati considerati solo articoli in lingua inglese. Il criterio di inclusione per una sintesi qualitativa era una popolazione di pazienti otosclerotici, sottoposti a chirurgia stapediale primitiva usando la protesi Nitinol, confrontati con altri tipi di protesi, paragonandone gli outcome funzionali. I criteri di inclusione per un'analisi quantitativa consistevano nell' applicazione delle linee guida dell'American Academy of Otolaryngology Head and Neck Surgery Committee on Hearing and Equilibrium per la valutazione della perdita trasmissiva. Il gap post-operatorio aria-osso $\leq 10 \mathrm{Db}$ è stato considerato efficace. Uno strumento di evidenza dei bias è stato sviluppato in accordo con le linee guida Cochrane. Per valutare l'età media del campione abbiamo usato il test chi-quadro. Dei 4926 lavori identificati attraverso la ricerca elettronica (3695 in Pubmed/Cochrane e 1231 in Embase), 540 lavori rispondevano ai criteri di selezione (436 in Pubmed/Cochrane and 104 in Embase) dopo l'applicazione dei filtri e l'eliminazione di articoli doppi. Dopo l'analisi di titolo ed abstract, 459 sono stati esclusi (396 in Pubmed/Cochrane e 63 in Embase). Dei rimanenti 81, 74 sono stati esclusi in base ai criteri di selezione dello studio. Un totale quindi di sette studi con 1385 pazienti, di cui 637 nel gruppo Nitinol e 748 nel gruppo non Nitinol, sono stati inclusi nel nostro lavoro. Vi erano differenze statisticamente significative sull'efficacia della chirurgia stapediale fra le protesi Nitinol e non Nitinol; i dati hanno dimostrato un odds ratio (OR) di 2,56 (95\% IC $1,38-4,6, p=0,003)$. Non vi sono state differenze statisticamente significative nell'età media preoperatoria fra le protesi Nitinol e non Nitinol ( $p=0,931)$. I nostri risultati suggeriscono che l' efficacia delle protesi Nitinol è maggiore di quelle non Nitinol.

PAROLE CHIAVE: Stapedotomia $\bullet$ Stapedectomia $\bullet$ Chirurgia stapediale $\bullet$ Otosclerosi $\bullet$ Protesi 


\section{Introduction}

Rehabilitation of conductive hearing loss is one of the major challenges in ear surgery. Since the 1950s, when stapes surgery for otosclerosis was introduced, there have been many changes in prosthetic design and materials. The success of stapes surgery may depend on the characteristics of the prosthetic material.

An ideal stapes piston should have good biocompatibility and adequate sound transmission. A variety of materials have been used as a piston between the incus and the stapes such as Teflon (fluoroplastic), titanium, stainless steel, platinum, and Nitinol. The new Nitinol piston was first used in stapes surgery in $2004{ }^{1}$. It is reasonable to summarise all other traditional prostheses as the non-Nitinol group.

The unique characteristic of the Nitinol piston is the auto-crimping process of the loop placed over the long process of the incus, allowing firm attachment of the piston in contrast with manual-crimping of the non-Nitinol group ${ }^{2-5}$. This technique may produce better functional results and reduce the risk of damage to the middle and inner ears during the crimping process ${ }^{5-8}$.

The present study, using a meta-analytical method, is designed to examine whether the new Nitinol prosthesis for otosclerosis surgery is superior to other previously mentioned non-Nitinol prostheses in terms of rehabilitation of conductive hearing loss and stability.

\section{Materials and methods}

\section{Search strategy}

A systematic literature review was carried out using the Medline, Embase, and Cochrane electronic databases. Using a combination of keywords including stapedotomy, stapedectomy and stapes surgery, a literature review was performed for studies in which the outcomes of stapedectomy and stapedotomy prostheses published from January 1970 to December 2016 were compared. All relevant papers or abstracts that were published in English were selected for the current investigation. The filters are shown in Table I.
Articles and data were independently extracted and evaluated for quantitative analysis by two coauthors from the included trials. If there was disagreement, a third reviewer was included and the issue was resolved by discussion.

\section{Study selection criteria}

Studies that included randomised control trials, retrospective and/or prospective ones were acceptable, and there was no limitation in age, sex, or follow-up periods. A postoperative air-bone gap $(\mathrm{ABG}) \leq 10 \mathrm{~dB}$ was considered effective. Depending on the available data, the postoperative gap of the ear that underwent surgery was calculated using pure tone audiometry (Table II) according to the guidelines of the Committee on Hearing and Equilibrium from the American Academy of OtolaryngologyHead and Neck Surgery criteria $(0.5,1,2,3 \text {, and } 4 \mathrm{kHz})^{9}$. Data on pre- and post-operative pure-tone average and ABG were compiled, and the mean thresholds were determined at $0.5,1,2$ and $3 \mathrm{kHz}$. When the threshold at $3 \mathrm{kHz}$ was not available, the average of the thresholds at $2 \mathrm{kHz}$ and $4 \mathrm{kHz}$ was estimated according to the new and revised reporting guidelines from the Committee on Hearing and Equilibrium. Studies that followed other quantitative standards were excluded from the current study in addition to duplicate studies (determined by examining the author lists, patient institutions, sample sizes and results). Investigations that included revision surgery, residency training, animal trials, and those that were classified as comments, editorials, or reviews were also excluded. Only the articles comparing postoperative effectiveness between Nitinol and non-Nitinol prostheses in primary otosclerosis surgery were used in our analysis. Moreover, we used the maximum follow-up date in cases of different follow-up times within the same article. To assess the potential influence by different surgery types, prostheses materials, follow-up periods and surgery procedures, we compared the effectiveness of Nitinol and non-Nitinol prostheses in several subgroups: (1) Nitinol or non-Nitinol material; (2) short-term ( $\leq 3$ months) follow-up period; (3) middle-term follow-up period (3

Table I. Filters activated.

\begin{tabular}{|c|c|}
\hline Filters & Characteristics \\
\hline Articles type & $\begin{array}{c}\text { Books and Documents, Classical Article, Clinical Conference, Clinical Study, Clinical Trial, Comparative Study, } \\
\text { Congresses, Consensus Development Conference, Controlled Clinical Trial, Evaluation Studies, Lectures, Meta-Analysis, } \\
\text { Multicentre Study, Pragmatic Clinical Trial, Randomised Controlled Trial, Review, Scientific Integrity Review, Systematic } \\
\text { Reviews }\end{array}$ \\
\hline Text availability & Abstract \\
\hline Publication dates & From $1970 / 01 / 01$ to $2016 / 12 / 31$ \\
\hline Languages & English \\
\hline
\end{tabular}


Table II. The average of the ABG was calculated on different respective frequency, from 500 to $4,000 \mathrm{~Hz}$. We used the mean threshold of four frequencies at least within this range; and assumed that a better value is used if the authors did not supply their calculation.

\begin{tabular}{lc} 
Frequencies $(\mathbf{k H z})$ & ABG average \\
$0.5,1,2,3$ & $4 \mathrm{ABG}$ \\
$0.5,1,2,4$ & $4 \mathrm{ABG}$ \\
$0.5,1,2,(2+4): 2$ & $5 \mathrm{ABG}$ \\
\hline
\end{tabular}

months to 3 years); or (4) long-term follow-up period ( $\geq 3$ years).

The quantitative data covered the number of subjects and of those who had reached a postoperative $A B G$ of $\leq 10 \mathrm{~dB}$, mean of pre- and post-operative ABGs, mean of followup times and number of excluded prostheses.

\section{Statistical analysis}

We performed a DerSimonian and Laird ${ }^{10}$ random-effects meta-analysis to pool effect sizes estimates across studies. The results were express in odds ratio (OR), with a $95 \%$ confidence interval (CI) calculated by Review Manager (RevMan), V.5.3 (Copenhagen: The Nordic Cochrane Centre, The Cochrane Collaboration, 2014) software. Evidence of heterogeneity was tested using $p$ value (with a $\mathrm{p} \leq 0.05$ indicating statistically significant heterogeneity) and $\mathrm{I}^{2}$ statistic ${ }^{11}$ (with an $\mathrm{I}^{2} \leq 25 \%$ indicating slight heterogeneity, an $\mathrm{I}^{2}$ between $25 \%$ and $50 \%$ indicating moderate heterogeneity, and an $\mathrm{I}^{2} \geq 50 \%$ indicating high heterogeneity) ${ }^{12}$. We used a random-effects model when $\mathrm{I}^{2} \geq 50$ $\%$ and/or $\mathrm{p} \leq 0.05$ because moderate heterogeneity was chosen. In the forest plot, the proportions are depicted with 95\% CIs according to Clopper and Pearson with the surface of the squares (point estimates) being proportional to the case number of the study. Funnel plots were tested for asymmetry. Egger's test was performed to evaluate potential asymmetry and publication bias.

\section{Results}

\section{Literature search and characteristics}

Of the 4926 papers identified through the electronic database search (3695 in Pubmed/Cochrane and 1231 in Embase), 540 investigations matched the selection criteria search (436 in Pubmed/Cochrane and 104 in Embase) after application of filters and elimination of duplicate articles (Fig. 1). However, 459 were excluded after analysis of the title and abstract (396 in Pubmed/Cochrane and 63 in Embase). Of the remaining 81 papers, 74 were excluded according to the study selection criteria. There was unanimity between the researchers regarding the selection of the relevant papers.

The seven trials covered 1385 subjects; 637 were sub-

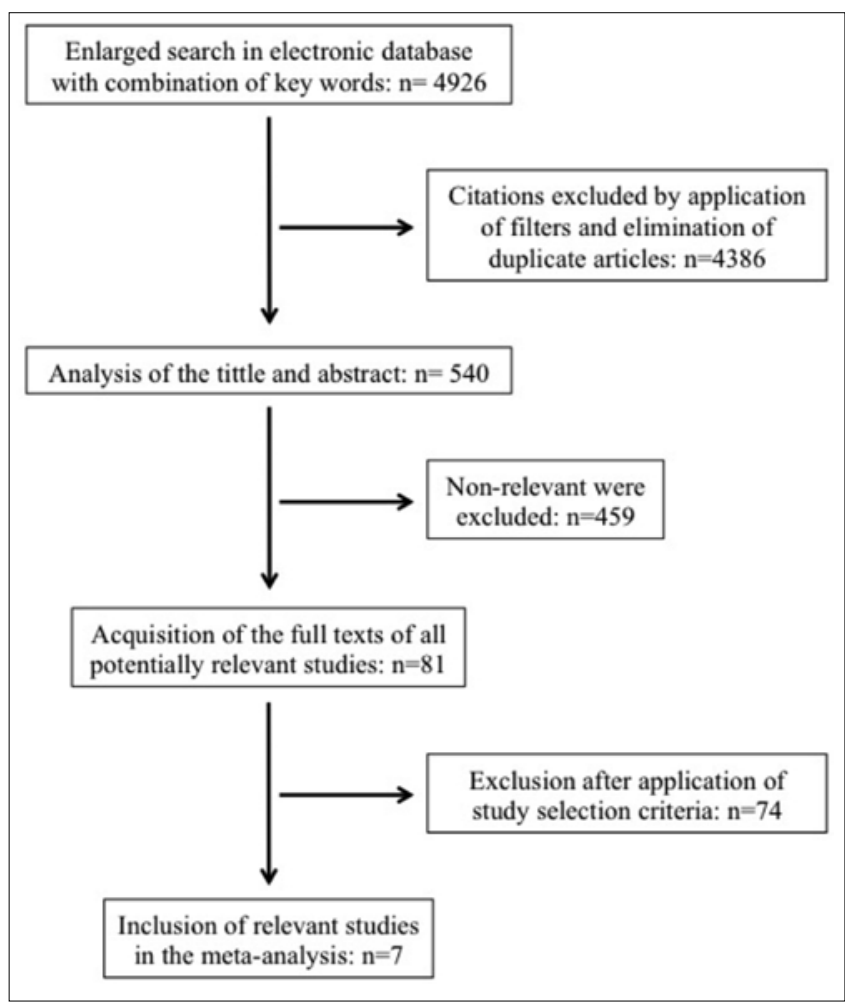

Fig. 1. Flow diagram showing the methodology of the study.

classified as the Nitinol group and 748 as the non-Nitinol grou $^{813-19}$. Of the seven investigations, two were found to be prospective reports, four were retrospective reports, and one was both a retrospective and prospective report. The post-operative hearing results were measured based on different frequencies. One study used $0.5,1,2$ and $4 \mathrm{kHz}$, four studies used $0.5,1,2$ and $3 \mathrm{kHz}$, and two studies used $0.5,1$ and 2 , and the average of the thresholds at $2 \mathrm{kHz}$ and $4 \mathrm{kHz}$. The characteristics of all the included trials are summarised in Table III.

\section{Meta-analysis}

The comparisons of prosthetic effectiveness and effectiveness with mean follow-up time between the Nitinol and non-Nitinol groups were performed using a meta-analysis (Fig. 2). For the analysis, subgroups were formed according to the follow-up periods (Figs. 3, 4).

In terms of the effectiveness of the prostheses, the test of heterogeneity was high $\left(\mathrm{I}^{2}=60 \%, \mathrm{p}=0.02\right)$, thus leading to a random-effects model. It was found that there were significant differences in the post-operative effectiveness of the prostheses between the Nitinol and non-Nitinol groups with a combined OR of 2.56 (95\% CI 1.38-4.76, $\mathrm{p}=0.003)$. Different results were found when the follow-up period was considered. Of the two studies with short-term results 
Table III. Characteristics of the trials included in the meta-analysis.

\begin{tabular}{|c|c|c|c|c|c|c|c|c|c|c|c|}
\hline Reference & Year & $\begin{array}{l}\text { Study } \\
\text { type }\end{array}$ & N & $\begin{array}{c}\text { Mean } \\
\text { age } \\
\text { (years) }\end{array}$ & $\begin{array}{l}\text { Prosthesis } \\
\text { type }\end{array}$ & $\begin{array}{c}\text { Pre-op. } \\
\text { ABG } \\
\text { (dB) }\end{array}$ & $\begin{array}{c}\text { Post-op. } \\
\text { ABG } \\
\text { (dB) }\end{array}$ & $\begin{array}{c}A B G \\
\text { improve- } \\
\text { ment }\end{array}$ & $\begin{aligned} & A B G \\
\leq & 10 \mathrm{~dB} \\
& (\%)\end{aligned}$ & $\begin{array}{l}\text { Follow-up } \\
\text { (months) }\end{array}$ & $\begin{array}{c}\text { Complications } \\
(\%)\end{array}$ \\
\hline Rajan et al. ${ }^{13}$ & 2007 & prospective & $\begin{array}{c}90 \\
270\end{array}$ & $\begin{array}{l}45.3 \\
42.5\end{array}$ & $\begin{array}{l}\text { Nitinol } \\
\text { titanium }\end{array}$ & $\begin{array}{l}38.24 \\
37.15\end{array}$ & $\begin{array}{c}5.15 \\
12,37\end{array}$ & $\begin{array}{l}32.4 \mathrm{~dB} \\
31.1 \mathrm{~dB}\end{array}$ & $\begin{array}{l}90 \\
75\end{array}$ & 24 & 0.01 \\
\hline Huber AM et al. ${ }^{8}$ & 2008 & $\begin{array}{l}\text { prospective } \\
\text { retrospective }\end{array}$ & $\begin{array}{l}75 \\
75\end{array}$ & $\begin{array}{l}44 \\
46\end{array}$ & $\begin{array}{c}\text { Nitinol } \\
\text { conventional }\end{array}$ & - & $\begin{array}{c}8 \\
11.6\end{array}$ & - & $\begin{array}{l}71 \\
43\end{array}$ & $\begin{array}{l}12.8 \\
13.1\end{array}$ & 1 \\
\hline Fayad JN et al. ${ }^{14}$ & 2009 & retrospective & $\begin{array}{l}306 \\
110\end{array}$ & $\begin{array}{l}47.9 \\
48.3\end{array}$ & $\begin{array}{l}\text { Smart (Nitinol) } \\
\text { non-smart (other) }\end{array}$ & $\begin{array}{l}26.1 \\
25.7\end{array}$ & $\begin{array}{l}7.6 \\
6.0\end{array}$ & $\begin{array}{l}18.7 \mathrm{~dB} \\
19.9 \mathrm{~dB}\end{array}$ & $\begin{array}{c}9.6 \\
11.3\end{array}$ & $\begin{array}{l}5.6 \\
6.9\end{array}$ & $\begin{array}{l}7.15 \\
10.1\end{array}$ \\
\hline Kuo CL et al. ${ }^{15}$ & 2010 & retrospective & $\begin{array}{l}16 \\
21\end{array}$ & $\begin{array}{l}42.8 \\
45.5\end{array}$ & $\begin{array}{c}\text { Nitinol } \\
\text { manual-crimping }\end{array}$ & $\begin{array}{l}26.79 \\
26.19\end{array}$ & $\begin{array}{c}7.92 \\
13.09\end{array}$ & $\begin{array}{c}14.53 \mathrm{~dB} \\
9.04 \mathrm{~dB}\end{array}$ & $\begin{array}{l}75.0 \\
33.3\end{array}$ & $\begin{array}{l}2.98 \\
3.27\end{array}$ & - \\
\hline Cho JJ et al. ${ }^{16}$ & 2011 & retrospective & $\begin{array}{l}80 \\
21\end{array}$ & $\begin{array}{l}46 \\
45\end{array}$ & $\begin{array}{c}\text { Nitinol } \\
\text { titanium (Fisch-type) }\end{array}$ & $\begin{array}{l}25.1 \\
28.1\end{array}$ & $\begin{array}{l}8.2 \\
9.0\end{array}$ & - & $\begin{array}{l}92.5 \\
95.2\end{array}$ & 12 & - \\
\hline Brar T et al. ${ }^{17}$ & 2012 & prospective & $\begin{array}{l}20 \\
20\end{array}$ & $\begin{array}{l}\text { (range } \\
18-45)\end{array}$ & $\begin{array}{l}\text { Nitinol } \\
\text { teflon }\end{array}$ & $\begin{array}{l}36.1 \\
34,3\end{array}$ & $\begin{array}{l}7.6 \\
8.1\end{array}$ & $\begin{array}{c}78.95 \% \\
76.3 \%\end{array}$ & $\begin{array}{l}100 \\
90\end{array}$ & 6 & 12.5 \\
\hline Canu G et al. ${ }^{19}$ & 2016 & retrospective & $\begin{array}{c}50 \\
50 \\
131 \\
50\end{array}$ & $\begin{array}{l}45 \\
43 \\
45 \\
46\end{array}$ & $\begin{array}{c}\text { Nitinol } \\
\text { teflon } \\
\text { first titanium } \\
\text { last titanium }\end{array}$ & $\begin{array}{l}22 \\
22 \\
25 \\
21\end{array}$ & $\begin{array}{c}6 \\
10 \\
10 \\
5\end{array}$ & $\begin{array}{l}16 \mathrm{~dB} \\
12 \mathrm{~dB} \\
15 \mathrm{~dB} \\
16 \mathrm{~dB}\end{array}$ & $\begin{array}{l}84 \\
36 \\
44 \\
92\end{array}$ & $\begin{array}{l}1 \\
3 \\
3 \\
1\end{array}$ & - \\
\hline
\end{tabular}

\begin{tabular}{|c|c|c|c|c|c|c|c|c|c|}
\hline \multirow{3}{*}{$\begin{array}{l}\text { Study or Subgroup } \\
\text { Brar et al } \\
\text { Canu et al }\end{array}$} & \multicolumn{2}{|c|}{ Nitinol } & \multicolumn{2}{|c|}{ Non-Nitinol } & \multirow{2}{*}{$\begin{array}{r}\text { Weight } \\
3.5 \%\end{array}$} & \multirow{2}{*}{$\begin{array}{c}\begin{array}{c}\text { Odds Ratio } \\
\text { M-H, Random, 95\% Cl }\end{array} \\
5.54[0.25,123.08]\end{array}$} & \multicolumn{2}{|c|}{$\begin{array}{c}\text { Odds Ratio } \\
\text { M-H, Random, } 95 \% \mathrm{Cl}\end{array}$} & \\
\hline & 20 & 20 & 18 & 20 & & & & & $\longrightarrow$ \\
\hline & 42 & 50 & 122 & 231 & $18.8 \%$ & $4.69[2.11,10.43]$ & & $\longrightarrow$ & \\
\hline Cho et al & 74 & 80 & 20 & 21 & $6.3 \%$ & $0.62[0.07,5.42]$ & & & \\
\hline Fayad et al & 29 & 306 & 12 & 110 & $20.1 \%$ & $0.85[0.42,1.74]$ & - & - & \\
\hline Huber et al & 53 & 75 & 32 & 75 & $20.7 \%$ & $3.24[1.65,6.36]$ & & 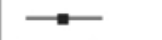 & \\
\hline Kuo et al & 12 & 16 & 7 & 21 & $10.9 \%$ & $6.00[1.41,25.59]$ & & & \\
\hline Rajan et al & 81 & 90 & 203 & 270 & $19.7 \%$ & $2.97[1.41,6.24]$ & & 一 & \\
\hline Total $(95 \% \mathrm{Cl})$ & & 637 & & 748 & $100.0 \%$ & $2.56[1.38,4.76]$ & & & \\
\hline Total events & 311 & & 414 & & & & & & \\
\hline $\begin{array}{l}\text { Heterogeneity: Tau }{ }^{2} \\
\text { Test for overall effect }\end{array}$ & $\begin{array}{l}0.36 ; C h \\
z=2.98\end{array}$ & $\begin{array}{l}\mathrm{i}^{2}=15 \\
(\mathrm{P}=0\end{array}$ & $\begin{array}{l}5.17, \mathrm{df}= \\
.003)\end{array}$ & $6(P=$ & $0.02) ; 1^{2}$ & $=60 \%$ & $0.01 \quad 0.1$ & $\begin{array}{c}10 \\
\text { Favours nitinol }\end{array}$ & $\overrightarrow{100}$ \\
\hline
\end{tabular}

Fig. 2. Forest plot of the odds ratio $(\mathrm{OR})$ for the number of patients achieving a postoperative $A B G \leq 10$ in the Nitinol group vs non-Nitinol group.

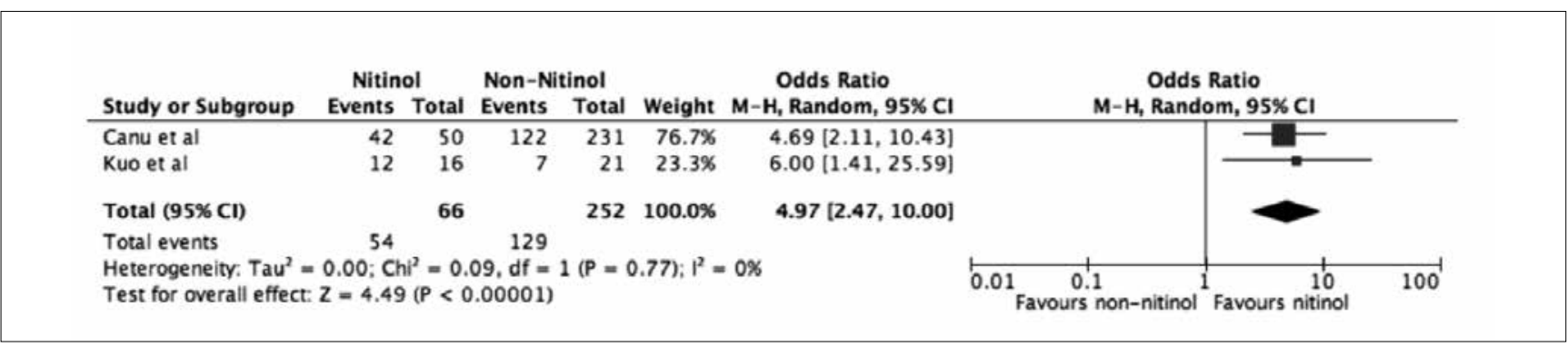

Fig. 3. Forest plot of the risk ratio (RR) for the number of patients achieving a short-term postoperative $A B G \leq 10$ in the Nitinol group vs non-Nitinol group.

( $\leq 3$ months), the postoperative effectiveness between the Nitinol and non-Nitinol groups had a combined OR of 4.97 (95\% CI: 2.47-10.00, $\mathrm{p}=0.00001$ ), with a slight heterogeneity $\left(\mathrm{I}^{2}=0 \%, \mathrm{p}=0.77\right)$. In the five studies with middle-term results ( 3 months to 3 years), the postoperative effectiveness between the Nitinol and non-Nitinol groups had a combined OR of 1.91 (95\% CI: 0.91-3.99, $\mathrm{p}=0.08)$ with high heterogeneity $\left(\mathrm{I}^{2}=60 \%, \mathrm{p}=0.04\right)$. There were no studies with long-term results ( $\geq 3$ years). There were no statistically significant differences in the mean age between the Nitinol and non-Nitinol groups with the adjusted chi-square test $\left[\chi^{2}(11)=5,000 ; p=0.931\right]$. 


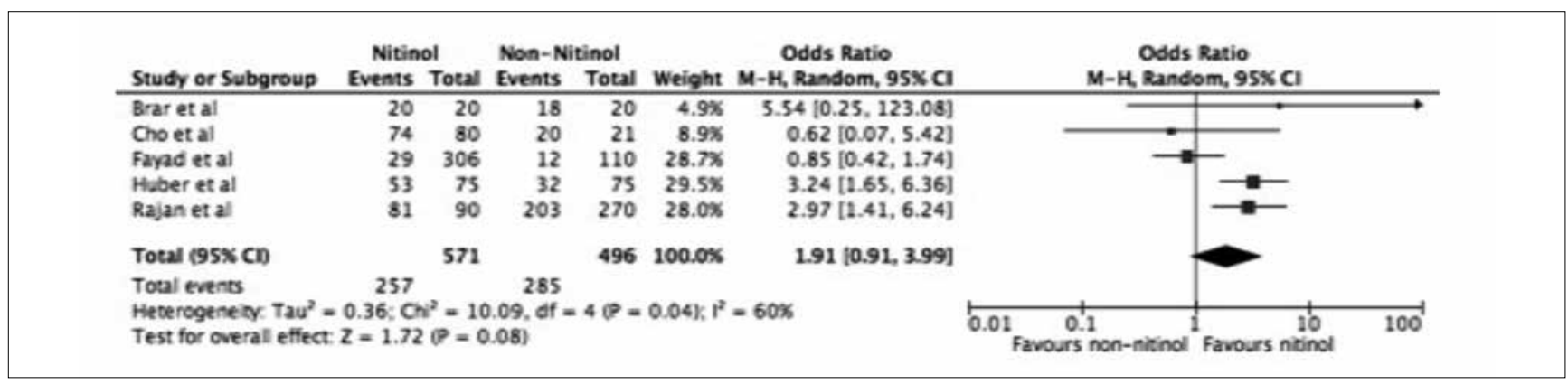

Fig. 4. Forest plot of the risk ratio (RR) for the number of patients achieving a middle-term postoperative $A B G \leq 10$ in the Nitinol group vs Non-nitinol group.

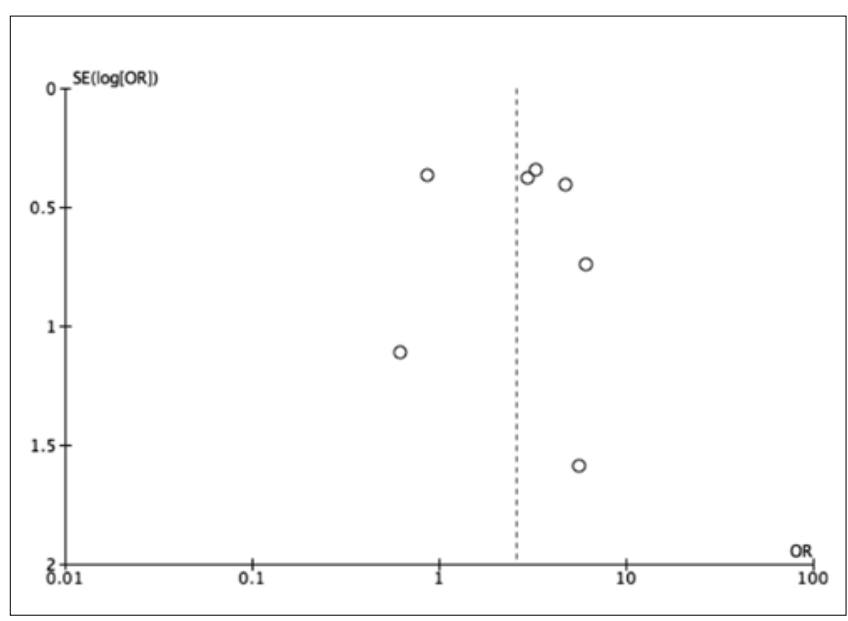

Fig. 5. Funnel plot for the included trials.

\section{Sensitivity analysis and publication bias}

The visual assessment of the funnel plot revealed no evidence of obvious publication bias (Fig. 5), nor did the formal evaluation using Egger test (intercept was 0.25, $95 \%$ CI -3.82 to $4.33, \mathrm{p}=0.879$ ).

\section{Discussion}

Teflon was the first material to be used in a stapedectomy by John Shea in $1956^{20}$. Since then there have been many changes in the design and materials used for stapes surgery. Nowadays, Teflon and Titanium (introduced by Kurz Medical Inc. in 1996) are probably the two most common prosthetic materials in use. We chose to study the Nitinol prosthesis because of the ongoing debate about its usefulness and superiority.

Nitinol is an alloy composed of titanium and nickel that has the properties of a shape-memory metal. By heating this metal above a certain temperature, its shape transforms into a predefined form ${ }^{21}$. Thereby, the loop closes on its own, and manual crimping is avoided. It has been proposed that this technique may produce better functional results because of improved sound transmission between the incus and the prosthesis with less variability and a diminished risk for the middle and inner ears during the crimping process ${ }^{13}$.

Van Rompaey et al. estimated that a sample size of at least 413 patients is needed in both the intervention and the control groups, in order to detect the smallest difference that is clinically important ${ }^{22}$. In our study, we used data from 1385 patients. To collect the meta-analysis data, we analysed the literature that compared the differences between Nitinol and non-Nitinol prostheses. The value of an ossicular prosthesis depends mainly on rehabilitation of conductive hearing loss and rate of prosthesis exclusion. Thus, we compared the number of patients achieving post-operative $\mathrm{ABGs}$ of $\leq 10 \mathrm{~dB}$ in the Nitinol and non-Nitinol groups. We found that there were significant differences between the two groups in conductive hearing loss rehabilitation.

When we divided our data into short-and middle-term follow-up periods, we found significant differences in shortterm period between these two groups, but we did not find the same significant differences in middle-term follow-up periods. We cannot make a clear judgment about the influence of the follow-up periods and hearing results.

The major concern in using Nitinol prosthesis is the longterm stability of the incus. The pathogenesis of incus erosion and necrosis appears to be controversial and may be affected by having the wire tightly wrapped around it and the heat applied to the prosthesis for the crimping ${ }^{23} 24$. All of the studies in our review mentioned the use of the surgical technique without exclusion. However, other studies refer lateral displacement of the prosthesis out of the vestibule and/or incus, between 8.7 to $11 \%{ }^{25}{ }^{26}$. Longterm data are presently lacking, both concerning hearing outcomes and risks of necrosis to the long process of the incus.

No major complications were reported. Three of the stud- 
ies did not even mention complications ${ }^{15} 16$ 19. Some transient and minor complications (tinnitus, vomiting, and vertigo) were described ${ }^{14}{ }^{17}$. Three cases of fixation of the malleus underwent revision surgery ${ }^{13}{ }^{27}$. No evidence of incus erosion due to the prosthesis was reported.

As to assessment of prostheses efficacy for sound transmission, the heterogeneity test of $\mathrm{I}^{2}$ demonstrated that there was significant heterogeneity among the enrolled studies, which probably could be ascribed to the different types of studies, follow-up periods, measurement frequencies, pre-operative hearing conditions, participating surgeons, prostheses and surgical techniques. From the additional sensitivity analysis, we found no evidence of obvious publication bias.

Meta-analysis is the pooling of data from several different investigations and objectively re-analysing the resulting data set to provide a more reliable reference for a clinical decision. Limitations regarding the surgical technique, various types of prostheses used and different follow-up periods were found. In view of the limitations of the current study, future studies should be based on prospective cohort or randomised studies with standardised unbiased methods, larger sample sizes, and longer follow-up periods in order to pursue more reliable implications.

\section{Conclusions}

Our meta-analysis indicated that the Nitinol prosthesis showed significant superiority to the non-Nitinol prostheses in terms of effectiveness and stability. Even though the user-friendliness of non-Nitinol prostheses has been confirmed, the disadvantage of expense should also be considered. Therefore, we recommend that a Nitinol prosthesis be chosen for the patient with otosclerosis with consideration of the budget, surgical difficulty and surgeon's proficiency in handling different prostheses.

\section{Acknowledgements}

We thank Joao Carmo for the statistical analyses included in this study.

\section{References}

1 Bast F, Weikert S, Schrom T. Treatment of otosclerosis with a superelastic Nitinol piston: first results. Indian J Otolaryngol Head Neck Surg 2011;63:126-31.

2 Blayney AW, Williams KR, Rice HJ. A dynamic and harmonic damped finite element analysis model of stapedotomy. Acta Otolaryngol 1997;117:269-73.

3 Fisch U. Stapedotomy versus stapedectomy. Am J Otol 1982;4:112-7.
4 McGee TM. The loose wire syndrome. Laryngoscope 1981;91:1478-83.

5 Shambaugh GE, Jr. Factors influencing results in stapes surgery a long-term evaluation. Ann Otol Rhinol Laryngol 1967;76:599-602.

6 Kurokawa H, Goode RL. Sound pressure gain produced by the human middle ear. Otolaryngol Head Neck Surg 1995;113:349-55.

7 Huttenbrink KB. Biomechanics of stapesplasty: a review. Otol Neurotol 2003;24:548-57; discussion 57-9.

8 Huber AM, Ma F, Felix H, et al. Stapes prosthesis attachment: the effect of crimping on sound transfer in otosclerosis surgery. Laryngoscope 2003;113:853-8.

9 Monsell EM. New and revised reporting guidelines from the Committee on Hearing and Equilibrium. American Academy of Otolaryngology-Head and Neck Surgery Foundation, Inc. Otolaryngol Head Neck Surg 1995;113:176-8.

10 DerSimonian R, Laird N. Meta-analysis in clinical trials. Control Clin Trials 1986; 7:177-88.

11 Deeks JJ AD, Bradburn MJ. Statistical methods for examining heterogeneity and combining results from several studies in meta-analysis. Systematic reviews in health care: meta-analysis in context. $2^{\text {nd }}$ ed. London: BMJ Publication Group; 2001.

12 Deeks JJ HJ, Altman DG. Cochrane handbook for systematic reviews of interventions version 5.1.0 (updated March 2011). The Cochrane Collaboration; 2011.

13 Rajan GP, Diaz J, Blackham R, et al. Eliminating the limitations of manual crimping in stapes surgery: mid-term results of 90 patients in the Nitinol stapes piston multicenter trial. Laryngoscope 2007;117:1236-9.

14 Fayad JN, Semaan MT, Meier JC, et al. Hearing results using the SMart piston prosthesis. Otol Neurotol 2009;30:1122-7.

15 Kuo CL, Wang MC, Shiao AS. Superiority of nitinol piston over conventional prostheses in stapes surgery: first comparative results in the Chinese population in Taiwan. J Chin Med Assoc 2010;73:241-7.

16 Cho JJ, Yunker WK, Marck P, et al. Effectiveness of the heatactivated nitinol smart piston stapes prosthesis in stapedectomy surgery. J Otolaryngol Head Neck Surg 2011;40:8-13.

17 Brar T, Passey JC, Agarwal AK. Comparison of hearing outcome using a Nitinol versus Teflon prosthesis in stapedotomy. Acta Otolaryngol 2012;132:1151-4.

18 Revesz P, Szanyi I, Rath G, et al. Comparison of hearing results following the use of NiTiBOND versus Nitinol prostheses in stapes surgery: a retrospective controlled study reporting short-term postoperative results. Eur Arch Otorhinolaryngol 2016;273:1131-6.

19 Canu G, Lauretani F, Russo FY, et al. Early functional results using the nitibond prosthesis in stapes surgery. Acta Otolaryngol 2017;137:259-64.

20 Shea JJ, Jr. A personal history of stapedectomy. Am J Otol 1998;19:S2-12.

21 Knox GW, Reitan H. Shape-memory stapes prosthesis for otosclerosis surgery. Laryngoscope 2005;115:1340-6. 
22 Van Rompaey V, Claes G, Potvin J, et al. Systematic review of the literature on nitinol prostheses in surgery for otosclerosis: assessment of the adequacy of statistical power. Otol Neurotol 2011;32:357-66.

23 Anson BJ, Winch TR. Vascular channels in the auditory ossicles in man. Ann Otol Rhinol Laryngol 1974;83:142-58.

24 Skinner M, Honrado C, Prasad M, et al. The incudostapedial joint angle: implications for stapes surgery prosthesis selection and crimping. Laryngoscope 2003;113:647-53.

25 Comacchio F, Markova V, Abousiam M. Patterns offailure in nitinol heat-activated crimping prosthesis after stapedotomy. In: Proceedings of the XXXI World Congress of Audiology. Moscow; 2012.

26 Ying YL, Hillman TA, Chen DA. Patterns of failure in heatactivated crimping prosthesis in stapedotomy. Otol Neurotol 2011;32:21-8.

27 Huber AM, Veraguth D, Schmid S, et al. Tight stapes prosthesis fixation leads to better functional results in otosclerosis surgery. Otol Neurotol 2008;29:893-9.

Received: September 28, 2017 - Accepted: March 2, 2018

Address for correspondence: Luis Roque Reis, Department of Otolaryngology of Egas Moniz Hospital, Centro Hospitalar de Lisboa Ocidental (CHLO), NOVA Medical School, Junqueira Street 126, 1340019 Lisbon, Portugal. Tel. + 351 91886251. E-mail: roquereis@sapo.pt 